\title{
Ecological Restoration in Protected Area of Peat Swamp Forest as an Effort to Build Socio-Ecological Resilience in Sebangau National Park Central Kalimantan, Indonesia
}

\author{
Anna Amalia ${ }^{1}$ \\ Ministry of Development Planning/BAPPENAS RI
}

\begin{abstract}
Peat forests are unique and sensitive ecosystems, have complex hydrological systems and bear important economic service functions. In Southeast Asian countries, peatland degradation has been increasingly severe in the last decade due to the exploitation of natural resources, which concerns the structure and function of the system. Ecological rehabilitation, including hydrological restoration, is believed to be useful for restoring the function of forest/peat swamp systems. Protection of critical areas in the form of National Park is also applied to reduce disturbance and further degradation of the area. A literature review is conducted to analyze the extent to which ecological restoration can achieve system resilience, especially socio-ecological resilience as a 'complex-adaptive system' using resilience concepts. The linkage between the ecological function of peat forest restoration by restoring hydrological systems, the diversity of flora and fauna, and enhancing social resilience with social networking and community livelihood is an important key in achieving resilience. Area Protection (in the form of National Park) needs to pay attention to interconnection systems in the "panarchy" model, not for system isolation, but directed to strengthening effective adaptation governance. The study of the selected Sebangau peatland forest in Central Kalimantan, which implemented hydrological restoration and post-Mega Rice Project (MRP) National Park to restore $85 \%$ of the damaged land. Sebangau peatland 'socio-ecological resilience' is assessed to increase after the restoration and determination of the national park, although peatland clearance still continues. Strengthening governance of national park and controlling on the main variables of peat and 'sustainable livelihood' is essential to improve resilience.
\end{abstract}

Keywords: Peat, forest, ecology, natural resources 
Ecological Restoration in Protected Area of Peat Swamp Forest as an Effort to Build Socio-Ecological Resilience in Sebangau National Park - Central Kalimantan, Indonesia

\author{
Anna Amalia, BAPPENAS
}

\title{
1. Introduction
}

Peatland is an essential wetland ecosystem made from peat soil with decomposed organic layer (Page \& Baird 2016) within waterlogged and oxygen deficiency condition (Cole et al. 2015). Its unique ecosystem with the complex hydrological system has important roles as a provider of ecosystem services provision as carbon sequestration and storage, biodiversity protection (Cole et al. 2015; Stephanie et al. 2017), control water catchment, flood mitigation and prevent saline water intrusion (Chokkalingam et al. 2005). PSF also supports the flora-fauna diversity and human community livelihoods (Boehm \& Siegert 2001).

Before the 1980s, there was less number of inhabitant in peatland ecosystem. In the last two decades, however, a significantly massive utilization of peatland occurred for harvesting its resources and settlement (Ceruti 2016; Page et al. 2009a). As consequence, deforestation and degradation impacted on the loss of biodiversity, decreasing the function of ecosystem services, disasters: land subsidence, flood and forest fire, and loss of community livelihood (Cole et al. 2015; Page et al. 2009a). Ecological Restoration is subsequently widely used to revive the natural function of the degraded ecosystem (Page \& Baird 2016; Page et al. 2009b). Furthermore, the designated protected area, such as national park at PSF, is believed to address the challenge in ecosystem resilience; support the biodiversity conservation that is subsequently beneficial for the community livelihood (Parker 2013).

In Sebangau, Central Kalimantan (Borneo), Indonesia, massive peatland forest destruction happened during the implementation Mega Rice Project (MRP) and the prolonged dry season in 1997/1998 (Page et al. 2009b). As a result, the landscape was almost entirely destructed, the community could not carry its socio-economic system in its natural regime. Having those catastrophic conditions, the government initiated to stop MRP, restored the critical ecosystem, and designated a National Park in 2006 to protect the area from further destruction. Those attempts aimed brought the ecological function back, that supports the future resilience in PSF landscapes.

This paper will discusses the role of ecological restoration in Protected Area (PA)/National Park Sebangau, Central Kalimantan, in building of socio-ecological resilience; exploring to what extent the restoration applied in an almost entirely destructed ecosystem can achieve socioecological resilience, including how the community can gain the adaptive capacity to maintain the future sustainability of reshaped ecosystem. Literature review on the interrelation of PSF and ecological restoration and viewing ecological restoration and protected area through socioecological resilience lens is used for framing the essential theory in both practices.

\section{Literature Review}

\subsection{PSF System and Ecological Perturbation}

Peatlands are not a single ecosystem type (Dielman et al. 2015). They are complex adaptive systems with closed-linked between peat carbon and water budget (Waddington et al. 2015), comprising of the holistic system of vegetation, fauna, and livelihood dependency (Cole et al. 2015). With peat soil composition as the primary cover, the ecosystem heavily relies on the water level, to maintain its services (Cole et al. 2015). The water level depth needs to be kept between $40 \mathrm{~cm}$ underground and $100 \mathrm{~cm}$ above the peat surface to avoid dried-fire to occur (Wösten et al. 2008). To maintain vegetation growth; additionally, the threshold for water tables depth is approximately 40 to $50 \mathrm{~cm}$. At this level, peatland flora can absorb water optimally via capillarity system (Waddington et al. 2015).

Palaeoecological analysis revealed that PSF vegetation shows resilience to fire and climate variability in the late Holocene (Cole et al. 2015). Also, peatland ecosystem demonstrates its resilience in the long-term gradual climate and hydrological changes (Page \& Baird 2016). However, rapid anthropogenic perturbation in the massive scale concomitant with increased 
fire due to the warmer climate in the last couple years has caused the decline of the ecosystem resilience (Page \& Baird 2016; Cole et al. 2015). Population growth with massive demand for timber and agricultural land leads to the enormous pressure of its ecosystem (Cole et al. 2015). Agroforestry practices require drainage on the water saturated in peat, resulted on drying peat and $\mathrm{CO} 2$ release in the atmosphere. Those triggered the widely spreading and frequent forest fires during the drought that degrades the entire ecosystem (Whitfield et al. 2011). PSF is then considered sensitive to external perturbation, to temperature and precipitation changes (Cole et al. 2015).

\subsection{Understanding PSF System and Disturbance in the Resilience Lens}

Resilience concept offers the understanding of the system as a complex and holistic, in each component interacts and functions to build identity (Parker 2013). A complex system can self-organize toward disturbance and changes, wherein the system is characterized by a dynamic and sometimes unpredicted behaviour, as it is generated from component changes and selection processes (Walker \& Salt 2012). The original concept of resilience is to define the term of persistence and the system ability in absorbing changes and disturbances and keep maintaining its fundamental structure and function (Holling 1973). However, in framing PSF ecosystem as a complex adaptive system (Folke 2006), human is also inseparable and belongs to the ecological system (Walker \& Salt 2006). Resilience does not only focus on the persistence and robustness of the system but also develops the adaptive capacity of the system and community (Folke 2006).

As PSF ecosystem is perceived sensitive to rapid external disturbances (e.g. humaninduced depletion and climate changes) (Cole et al. 2015), Folke (2006) describes it is beneficial to recognize (1) the amount of perturbation can be absorbed by a system, while keep maintaining the same function and not switching to another steady state; (2) the degree of system able to do reorganization; and (3) the degree of system to enhance learning and adaptation capacity, to build social-ecological resilience. There are two ways in framing system resilience (Folke 2006; Walker \& Salt 2006). The first is about regime shifts. When a system can absorb the disturbances, and preserve its entity, the system is likely to stay in the same regime (Parker 2013). However, if there is a change in the system feedbacks and external disturbance that are exceeding the capacity to cope, the system might cross the threshold shift into a new regime, which might behave in undesirable and unforeseen surprises (Walker \& Salt 2006; Brown 2007). It is crucial to consider the current threshold, the distance of system to threshold, and how to avoid or cross to a regime shift (Parker 2013; Walker \& Salt 2006), notwithstanding sometimes a threshold effect is not visible in a system (Walker \& Salt 2012).

Another framework is the adaptive cycle, used for describing properties and dynamic in internal system link (Folke 2006; Walker \& Salt 2006). In different time and space scale, the system changes in four phases: rapid growth, conservation, release and reorganization (Figure 1) (Walker \& Salt 2012; Gunderson \& Holling 2002).

Figure 1. Adaptive Cycle Model

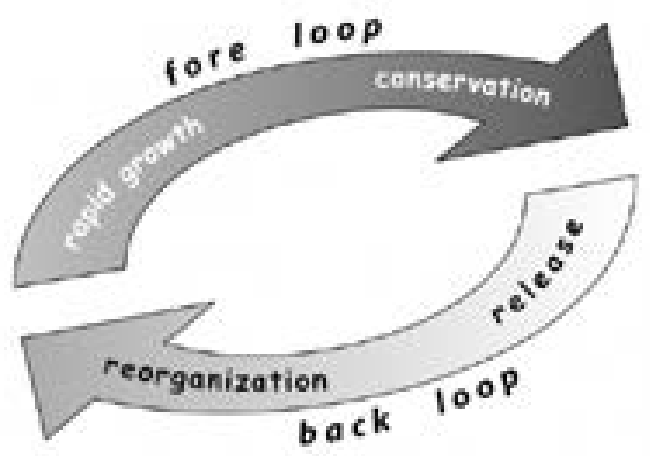

Source: Walker \& Salt, 2012 
In the rapid growth phase, species or actors exploit all potential ecological and social niche, with weak connection. Next step, conservation phase, resources incrementally circulated, and each component become strongly interconnected and regulated, as reflected on the hydrological system in peat swamp forest. When the connection becomes rigid and overconnected, the resilience might decline; shock can rapidly spread to all the system (Walker \& Salt 2006), such as a fire in drainage peatland in drought. In release phase, the system bound is released. Some of the systems can collapse, but "creative destruction" may become a source of reorganization and renewal (Walker \& Salt 2006). It is important to have deep comprehension in each phase of an adaptive cycle and to know where the system lies, since intervention might be appropriate and excellent in one cycle, but could not work in another cycle (Walker \& Salt 2006).

\subsection{The Potential of Ecological Restoration to Build Socio-Ecological Resilience in PSF Ecosystem}

The extensive utilization of PSF might move the system in the undesirable state (Brown 2007). Logging and peat drainage, for example, will increase the risk of fire which not only destroyed the biomass above but also goes through underlying peat, forcing in undesirable environment and impacts (Boehm \& Siegert 2001) and effected to the society. Ecological restoration, therefore, is needed to revive the new regime into a desirable system, reorganize system to build the resilience, and increase the capacity to cope with disturbance or manage the system away from threshold (Walker \& Salt 2006). Since the system assumes constantly change (Folke et al. 2010), managing resilience need to focus on the threshold and new potential states, rather than maintaining the system to achieve optimal state (Walker \& Salt 2006).

Ecological restoration is defined as a human intervention to restore the damaged natural resources function of the ecosystem and bring back the environmental and economic services (Page \& Baird 2016; Wösten, Rieley, \& Page, 2008). Ecological restoration comprises rehabilitating hydrological system, vegetation structure and dynamics, carbon sequestration, and storage capacity (Page \& Baird 2016; Wösten, Rieley, \& Page, 2008), and restoring local community livelihood (Page et al. 2009b). In a peatland system, restoration ecology becomes a pre-requisite on restoring water level in the peat soil, that will bring multiplier effect on entire system; establishing carbon balance and re-vegetation. As the system shows its integrity in the hydrological system, it could demonstrate resilience toward disturbance (Wösten, Rieley, \& Page, 2008).

Ecological restoration should consider the reintroduction of the various functional group of species with different characteristics that will shape the structure and system behaviour (Folke 2006), and allow the species in adjusting with rapid environmental change (Chapin et al. 2009). Diversity will enhance the ability of the system to absorb disturbance and maintain its fundamental function (Walker \& Salt 2012; Gunderson \& Holling 2002). Levin (1999) adds that biological diversity is essential in enhancing self-organizing ability, absorbing sequence perturbances, re-generating and reorganizing system after disturbance. Diminishing biodiversity function for self-organizations and bottom-up impacts (e.g. soil erosion or redirection of water flows and suppression of fire) can likely drive less desirable state with drawbacks on livelihood and societal development (Folke et al. 2004). Even though diversity might decline in the initial stage of restoration, it will increase along with the water-level rise (Tuittila et al. 2000).

The growth of ecological resilience will substantially foster the forming of social resilience, since both are interdependent, coupled, and coevolving (Berkes \& Folke 1998; Folke 2006). Notably, social resilience might be achieved when a group of societies can withstand external turmoil or shock from the changes of social, political, and environmental conditions (Adger 2000). In other words, community resilience is the community engagement and existence with resources in changed, uncertain, and surprised environment (Berkes \& Ross 2013). In the context of PSF where community resided is heavily dependent on its ecosystem services and forest resources (Stephanie et al. 2017; Page \& Baird 2016), the resilience of the inhabitant to protect their livelihood is related to the degree of ecological system resilience (Adger 2000). While forest resources depend on the way the ecosystem is maintained, the ecosystem restoration will be valuable for bringing the ecosystem back, and the livelihood of the community is likely to continue (Stephanie et al. 2017). The development of self-sustaining community and welfare (e.g., increase in social capital) can be achieved alongside the natural capital restoration, with strong adaptive management principle (Allen \& Gunderson 2011). 


\subsection{Concept of Resilience in the context of Protected Area (PA)}

PA was argued to be a useful method to conserve nature and natural resources, promote fairness in resource distribution and generation, and support community livelihood (Mukul et al. 2016). It also can reduce local stressor (Cote \& Darling 2010), such as logging in PSF or fishing on coral reefs marine PA (Parker 2013). However, Parker (2013); Cote \& Darling (2010) argue

Framing PA system, it needs to see Folke's (2006) underlying framework of resilience called "linked cycle". Through "Panarchy" model, the interconnection between systems is drawn, where the ability of a system to do adaptive renew and re-organization is influenced by the dynamic among system states or 'interplay' among scales that are delivered across times, at the level above and below (Figure 2). Resilience is subsequently likely to be built with a wider landscape view (Folke 2006), with maintaining modularity between systems to embrace learning and adaptive capacity (Walker \& Salt 2006), coping with local and global perturbations.

Figure 2. Panarchy Model

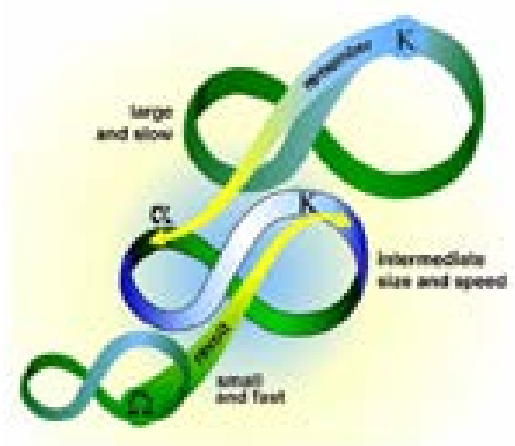

Source: Folke, 2006

Additionally, Walker \& Salt (2006) state that interconnectedness and feedbacks between ecosystem and social system must be taken into account. It means PA should not be used for isolating the system, but promoting adaptive governance with a high engagement of social capital (trust and social networks) (Parker 2013; Folke et al. 2010). Gunderson, Cosens \& Garmestani (2016) \& Gunderson and Light (2006) defined adaptive governance as the set of institutions and framework that facilitates and fosters adaptive management. A good adaptive governance needs to focus on community and stakeholder engagement, optimization of social capital, and social learning community, which will support the development of SES resilience (Parker 2013).

The effective adaptive governance develops from strong a correlation between science, governance, and practice (Wyborn 2015). Therefore, in bridging the rigidity of typical "commandand-control" environmental regulations, increasing the adaptive capacity in management can be used to adapt to "surprise", which characterized by history and local knowledge improvement (Germastani et al. 2009). Developing close partnerships with organizations like NGOs and universities will be beneficial to plan, coordinate and share the information (DeCaro et al. 2017).

\section{Analysis}

\subsection{Socio-Ecological System of Sebangau Peat Swamp Forest}

Southeast Asia own a large tropical peatland which covers about 24.8 million ha or $56 \%$ of the total area of the world's tropical peatland (Page et al. 2009b), and $83.5 \%$ of it is in Indonesia (Stephanie et al. 2017; Putra et al. 2008). Three million hectares of Indonesia peatland alone is located in the Sebangau Central Kalimantan Province (Boehm \& Siegert 2001). Sebangau Peat Swamp Forest (PSF), the largest intact tropical peatland in the world located over Katingan District, Pulau Pisau District and Palangka Raya Municipality, in lowland area between Sebangau River and Katingan River (WWF Indonesia, 2015).

Sebangau peatland was a pristine PSF, purely rain-fed and waterlogged throughout the year in its normal condition (Page et al. 2009b). Its unique ecosystem with the complex 
hydrological system has important roles as a provider of ecosystem services provision as carbon sequestration and storage, biodiversity protection (Cole et al. 2015; Stephanie et al. 2017), control water catchment, flood mitigation and prevent saline water intrusion (Chokkalingam et al. 2005). Calculated as $30 \%$ world's canopy, this ecosystem act as the largest carbon sink and sequestration, which approximately absorb 2.4 billion tonnes of CO2/year (Ceruti 2016) or 12\% of the World's peatland carbon (Cole et al. 2015). There are about specific 150 species of birds, 34 species of fish, 35 species of mammals (mainly orangutan) and 808 species of plant including trees and non-timber forest production (NTFP), that support around 62.000 local inhabitants (WWF Indonesia 2015; Taman Nasional Sebangau 2014).

\subsection{PSF Degradation and Social Impact due to the Development of Mega Rice Project (MRP)}

Massive peatland forest destruction happened in MRP implementation. During that period, $78 \%$ of forest cover has been degraded. MRP was established by Presidential Decree No. 82/1995 to reach the target of food self-sufficient program (Wösten, Rieley, \& Page, 2008). The understanding of peatland as an idle 'wasteland' with abundant water resources (save expenditure for irrigation) (Wösten et al. 2008) had driven the exploitation of the peatlands. Total area allocated for MRP was covered up to $1,457,000$ ha (divided into five blocks). To use peatland as agriculture, the project needed to drain waterlogged through channels (Figure 4) (Wösten, Rieley, \& Page, 2008). The excessive channels with total length were $4,473 \mathrm{~km}$ that cut through the center of peat domes (Ritzema et al. 2014), and land clearing was blamed for being the reasons behind the peat degradation and project failure.

Figure 3. Irrigation Channels built for MRP Project

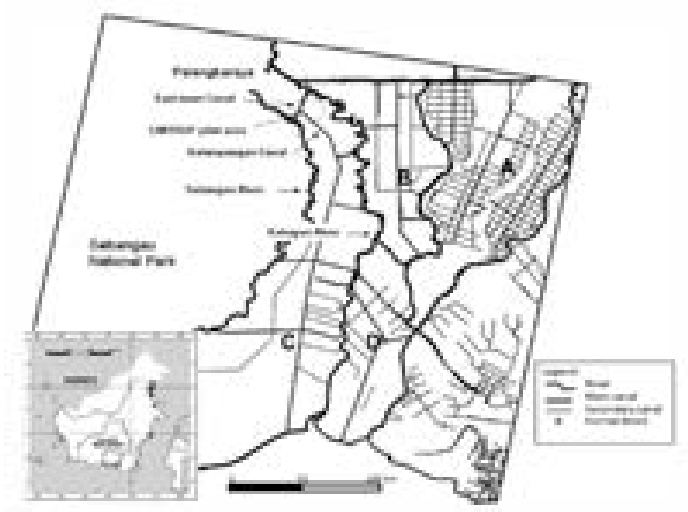

Source: Wösten, Rieley, \& Page, 2008

The MRP neglected the complex hydrological system in the peatlands that need specific management since drainage of one part of the hydrological unit might impact on the runoff, drainage, or subsidence of the entirety of the peat area (Stephanie et al. 2017). Water drained out from peatland drove water stressed vegetation and peat subsidence (Ritzema et al. 2014), increased the risk of fire severity, and loss of flora and fauna habitat (Wösten, Rieley, \& Page, 2008). The open canal system also allowed people to enter the previous inaccessible PSF area, including illegal loggers to exploit the timber out (Ritzema et al. 2014; Wösten, Rieley, \& Page, 2008). Moreover, MRP is also in parallel with transmigration program to move in Sebangau area, which added the land clearing practices through burning (Chokkalingam et al. 2005). The deforestation was acummulated by the El Nino Southern Oscillation (ENSO) in 1997, 1998 and 2002 (Wösten et al. 2008). The prolonged droughts ignited massive fire from mostly dried peat (Boehm \& Siegert 2001), and subsequently blanketed Borneo and other 15 million km2 Southeast Asia for several weeks (Wösten et al. 2008).

\subsection{Threshold Crossed: Socio-Ecological System (SES) move to Undesired State}

As the landscape was almost entirely destructed, the community cannot carry its SES in its natural regime or state. Local community primarily indigenous people lost their livelihood, e.g. from the NFTP (rubber, rattan, traditional rice fields, fish traps), and some had involved 
in illegal logging and mining. The critical peats and disasters (fire, flood, pests outbreak) lead the local people felt insecure and apathetic (Wösten, Rieley, \& Page, 2008). About 50\% of the transmigrants also left the area (Ritzema et al. 2014).

With the MRP implementation, the SES has moved beyond the threshold and dropped into undesired condition (Cole et al. 2015). In this regards, the system failed to absorb and cope with the disturbances from the high agricultural conversion and drought periods (Walker \& Salt 2006; Brown 2007). The record shows that during 3.5 years of MRP implementation, nothing has been yielded but deforested, fire-prone landscape, and hardship of inhabitants due to increased poverty (Wösten, Rieley, \& Page, 2008), low crop productivity, and animal and plant pests (Tuittila et al. 2000).

The system has changed from growth and conservation phases into a release phase, according to adaptive cycle (see Figure 1). Before the implementation of MRP, PSF served optimal ecosystem services to its surrounding and acted as a carbon sequestration. The peats were being slowly cleared for small-scale plantation and timber logging before 1996, but the system could continue its growth and conserved as the original cover remained (Boehm \& Siegert 2001). Throughout times, the connection between the ecological system of PSF and the social system became stronger. However, the massive exploitation through MRP has released the system bound, and the forest cover in MRP sites dropped from $64.8 \%$ in 1991 to $45.7 \%$ in 2000 (Table 1) (Boehm \& Siegert 2001). Negative impacts appeared, and the system failed to bounce back to play its functions.

Table 1. Forest Cover Change in Five MRP Region during 1991, 1997 and 2000

\begin{tabular}{|c|c|c|c|c|}
\hline 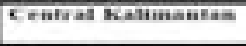 & & 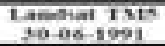 & 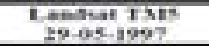 & 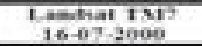 \\
\hline 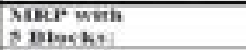 & 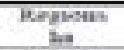 & $\begin{array}{c}\text { Pol thorewt } \\
\text { has }\end{array}$ & $\begin{array}{c}\text { indroweit } \\
\text { ka }\end{array}$ & $\begin{array}{c}\text { Dstiocent } \\
\text { pas }\end{array}$ \\
\hline Elock is & $\begin{array}{l}315304 \\
(10004)\end{array}$ & $\begin{array}{l}135535 \\
47956\end{array}$ & $\begin{array}{l}107350 \\
404\end{array}$ & $\begin{array}{l}30=3 \pi \\
12004\end{array}$ \\
\hline Giosk in & $\begin{array}{l}(6)+401 \\
(t 000 \mathrm{~s})\end{array}$ & $\begin{array}{l}100: 254 \\
\text { क? }\end{array}$ & $\begin{array}{l}92160 \\
51 \times 06\end{array}$ & $\begin{array}{l}31000 \mathrm{a} \\
17 \text { not }\end{array}$ \\
\hline Elocke & $\begin{array}{l}440760 \\
010066)\end{array}$ & $\begin{array}{c}235275 \\
22006\end{array}$ & $\begin{array}{l}160606 \\
10046\end{array}$ & $\begin{array}{l}73 \text { int } \\
\text { lowe }\end{array}$ \\
\hline nimes 13 & $\begin{array}{l}1.3007 \\
(10006)\end{array}$ & $\begin{array}{l}136 \\
3276\end{array}$ & $\infty$ & on \\
\hline Btoek $\mathrm{x}$ & $\begin{array}{l}305002 \\
(10004) \\
\end{array}$ & $\begin{array}{r}390.475 \\
70 \times 246 \\
\end{array}$ & $\begin{array}{l}383007 \\
\text { Joreth }\end{array}$ & $\begin{array}{l}350905 \\
21464\end{array}$ \\
\hline 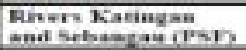 & $\begin{array}{l}350 \text { abb } \\
\text { (cones) }\end{array}$ & $\begin{array}{c}052056 \\
81,46\end{array}$ & $\begin{array}{l}631262 \\
35746\end{array}$ & $\begin{array}{l}573.921 \\
\text { sil. } 446\end{array}$ \\
\hline $\begin{array}{l}\text { Semin } \\
\text { for } 6 \text { reglons }\end{array}$ & $\begin{array}{l}2.404 .752 \\
100045\end{array}$ & $\begin{array}{c}\text { 1. } 260.357 \\
64.566 \\
(10046)\end{array}$ & 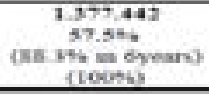 & 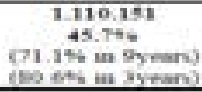 \\
\hline
\end{tabular}

Source: Boehm \& Siegert, 2001

\subsection{The Response through Ecological Restoration to bounce back the Degraded SES}

The massive drainages from MRP implementation have changed the primary hydrological system of PSF and lead to irreversible effect (Ritzema et al. 2014). Since it is impossible to allow the system to do self-reorganization after the release phase, it needs human intervention to accelerate the restoration of the degraded PSF (Wösten, Rieley, \& Page, 2008), to bring back a naturally functioning, self-sustaining ecosystem as quickly as possible (Tuittila et al. 2000). At first attempt, the government terminated the MRP project in June 1999 through Presidential Decree No. 80/1999 to stop the severe catastrophic condition. Several efforts afterwards have been demonstrated to rehabilitate the destructed PSF in Central Kalimantan.

The main phase of ecological restoration is hydrological restoration, rewetting the dried peat that is beneficial to prevent fires, peat oxidation (Jaenicke et al. 2010), establishing carbon balance and re-vegetation (Wösten, Rieley, \& Page, 2008). Blocking the built drainage channels by dams (canal blockings) construction for rewetting the peats from several projects has shown that the groundwater level can be increased up to 50-70 $\mathrm{cm}$ (under the very dry weather and peat conditions) (Jaenicke et al. 2010; Wösten, Rieley, \& Page, 2008), that potentially can triggering revegetation. According to Wösten et al. (2008), keep maintaining groundwater level between $40 \mathrm{~cm}$ and $100 \mathrm{~cm}$ above surface valuable for regeneration of high diversity native tree species. Local natural materials such as gelam timber poles and peat were used for canal blocking (Jaenicke et al. 2010), which were valuable since they are locally available and gradually become permanent as plant debris trapped and timber become vegetated (Yule 2010). 
Nevertheless, to build sustainability and recover the system resilience after the turbulance, the ecosystem and social system cannot be managed separately (Walker \& Salt 2006). Since ecological restoration also comprises restoring local community livelihood (Page et al. 2009b), restoration was regulated for rehabilitating and restoring the community system and source of incomes, through replanting the 'endemic living trees' (Wösten, Rieley, \& Page, 2008). Water management at the early stages will be beneficial for the re-growth of the plant. However, the degraded peat sometimes includes soil seed bank lost which inhibit the forest succession (Wösten et al. 2008). Therefore, it requires for re-introducing the diversity species to enhance the system capacity to absorb disturbance (Walker \& Salt 2012; Gunderson \& Holling 2002).

\subsection{Governing the PSF Socio-Ecological System}

The government of Indonesia tried to govern the peatland area in Central Kalimantan to suppress any further degradation, revitalize the ecological function, which supports the future resilience of both social and ecosystem system in PSF landscapes. Several regulations were enacted parallel with restoration programs. In Sebangau PSF, particularly, was designated as National Park on 19 October 2004 through Minister of Forestry Decree SK.423/MenhutII/2004 (WWF Indonesia 2015). National Park was expected become a buffer for ecosystem and biodiversity of the peat to leverage the benefit to the community inside and surround the peat, and to maintain the sustainability of the conserved area for future generations (Zakiah et al. 2015). Other regulations were also issued for regulating peatlands and strictly prohibiting the unsustainable peatland practices. For example Ministry of Agriculture Regulation No. 14/2009 (Guideline on Oil Palm Plantation on Peatland), Government Regulation No. 71/2014 (Protection and Management of Peatland Ecosystem), and a national level moratorium on deforestation of primary forests and peatlands through Presidential Instruction No. 10/2011 (Stephanie et al. 2017).

However, although the landscape has been given protected-area status, the PSF is not purely immune from challenges ahead. With the fact that forest regeneration is a long process, adding by continual illegal logging practices make the habitat that has undergone many years of disturbance, cannot be optimally restored (Wösten et al. 2008). At several years after implementation, the restoration projects resulted in slow progress on the term of forest cover (Table 2).

Table 2. Data of PSF cover between 1990-2010 in Southeast Asia

\begin{tabular}{|c|c|c|c|c|c|c|c|c|c|c|c|c|}
\hline & \multicolumn{2}{|c|}{1990} & \multicolumn{2}{|c|}{ 1990-3900 } & \multicolumn{2}{|c|}{2000} & \multicolumn{2}{|c|}{$\begin{array}{c}2000-2020 \\
\text { dhowe }\end{array}$} & \multicolumn{2}{|c|}{2010} & \multicolumn{2}{|c|}{$\begin{array}{c}1000-2020 \\
\text { dorex }\end{array}$} \\
\hline & $\mathrm{Am}^{3}$ & 8 & $\mathrm{kn}^{3}$ & $x_{r^{\prime}}$ & $\mathrm{km}^{7}$ & $\mathrm{x}$ & $\mathrm{km}^{3}$ & $\mathbf{x p r}^{2}$ & $\mathrm{ln}$ & 8 & $\mathrm{an}^{\prime}$ & $x_{p}^{\prime}$ \\
\hline Ponimis Mdrsis & 379 & 443 & -409 & -30 & 2808 & 328 & -54 & -20 & 2299 & 269 & -1497 & -25 \\
\hline Barnes & 4261 & 820 & -12892 & -30 & 36369 & 606 & -6964 & -28 & $2 j 655$ & 457 & -21795 & -2.9 \\
\hline Sarnest & asse & an) & -2476 & -29 & 7109 & 612 & -4104 & -6.1 & 3075 & 262 & -6581 & -56 \\
\hline West K K Lmantas & 12028 & 884 & -192 & -16 & 10916 & 75.2 & $-2 m b$ & 23 & exes & 5,8 & $-4 ! 40$ & -1.9 \\
\hline Ceneral Kinmentah & nim & 850 & 1670 & 86 & 15334 & 389 & 2005 & A. & 13258 & 510 & $=352$ & 625 \\
\hline fat Kalmuran & ins & (2) & -40 & -1.8 & 203 & 765 & -342 & -15 & 2053 & 656 & $-7 \pi$ & -1.6 \\
\hline The reet of Bornes & 1340 & 39.4 & $-12 \pi$ & -11.5 & 345 & 117 & -186 & -3 & ins & $\mathrm{n}$ & $-143 i$ & -75 \\
\hline
\end{tabular}

Source: Miettinen, Shi, \& Liew, 2012

In regards to governance, it is often not clear how policies or laws can upgrade or abrade resilience (Germastani et al. 2009). Ecological restoration in Sebangau PSF, however, needs to be seen as a preliminary policy and management to help the SES to rebuild its resilience, reorganize after the release stage, where it help the system to continue the adaptive cycle. Managing the hydrological system of the peat by focusing on the characteristic of hydrological condition in each of the blocks was effective to give peat system chance to be reestablished (Walker \& Salt 2006). However, the partially projects implementation brings uncertainty on what degree of resilience is achieved. Even so, the projects mostly presented active engagement process with the local community; increasing their awareness, shifting dependence behavior through creating the alternative livelihood, which is crucial for developing a social resilience.

Development of National Park when it is seen as a protected and isolated system was argued less resilience due to limited ability and diversity to reduce global disruption (Parker 2013; Cote \& Darling 2010). However, having Sebangau peatland under National Park 
Management (Figure 4) was the optimum way to maintain peat forest and build the resilience.

Figure 4. Sebangau National Park Map
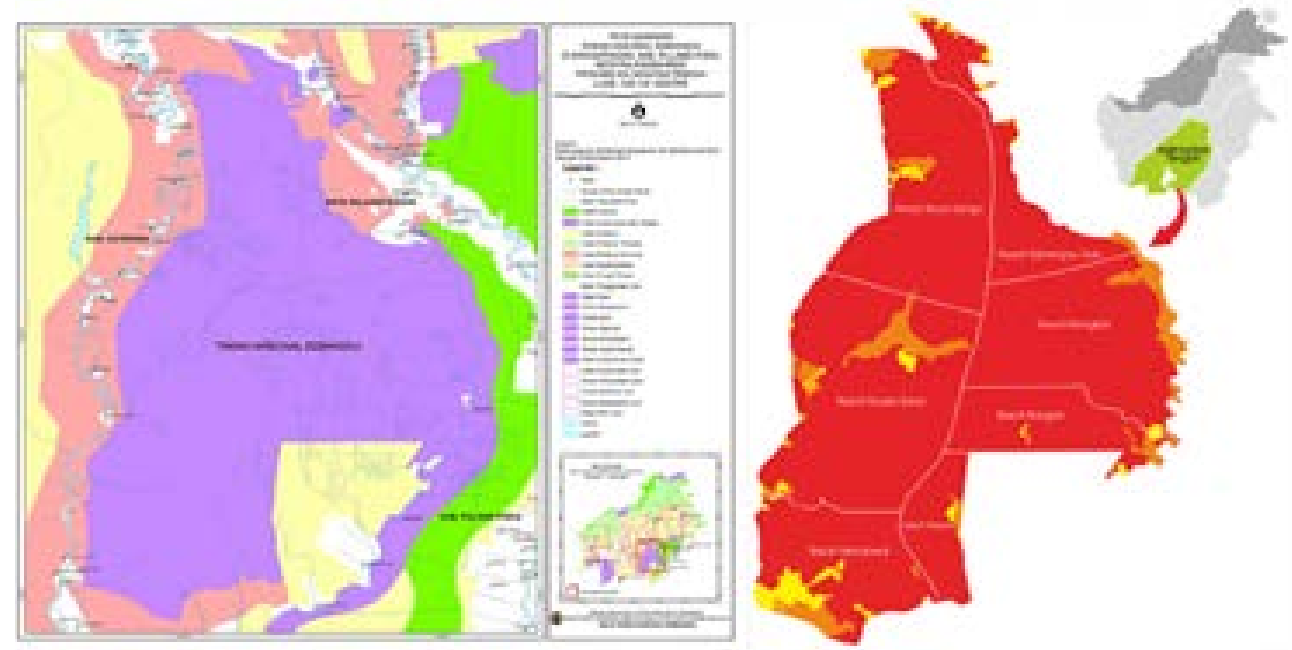

Source: Taman Nasional Sebangau, 2014

Currently, the governance of peatland in Sebangau is believed effective to protect the PSF landscape from further destruction. The functioning area into conservation, research and education, cultural, and tourism zones (Government of Indonesia 1998) is beneficial to set the priority actions for each zone, under one integrative management (Taman Nasional Sebangau 2014). The education and tourism zones, for example, give the opportunity for people to visit, learning and giving feedback on managing the Sebangau PSF, while cultural and conservation zones continue the buffering on peatland system. To date, Sebangau NP also pointed as the pilot model of sustainable peatland management in Indonesia (Taman Nasional Sebangau 2014).

Sebangau National Park also demonstrated adaptive management for bridging the rigidity of typical "command-and-control" environmental regulations, through increasing the adaptive capacity of society and stakeholders related, and enhancing the partnership between organizations; such as NGO, universities, national and international institutions to continuously improve the environmental management of the PSF. Adaptive capacity was developed through engagement with community in the rehabilitation, replantation programs, capacity building and awareness raising program, and community socio-economic development program (WWF Indonesia 2015). Using local knowledge as a main knowledge of specific site restoration is valuable since there is no "one size fits all" policy, which means, the flexibility of policies is derived based on particular issues on specific sites (Germastani et al. 2009; Walker \& Salt 2006). The Sebangau NP maintains welfare improvement program for giving alternative livelihood for community through introducing sustainable practices in eco-tourism, agriculture, fisheries, agroforestry and home industries, which are likely beneficial to strengthen the social capacity and reduce the dependency of people to exploit the Sebangau PSF natural resources (Mukul et al. 2016; WWF Indonesia 2015). The more pristine and managed the peat system, the more capacity to regulate water, carbon storage, and ecosystem services, that likely increase the ability in tackling the external or global stressor, such as climate change or political changes that might lessen the resilience of the system.

\subsection{Future Governance Improvement Needed}

As a developing country, Indonesia will still face the threats on forest exploitation including peatlands due to conflict of interests, economic and population growth, and highly dependence of 6-30 million people to the forest services and ecosystem (Cole et al. 2015). The challenge in managing tropical peatlands in the 21st century is to develop integrated planning and management approach to balance between peatland resource demands and to ensure the continued peatland ecosystem survival (Wösten, Rieley, \& Page, 2008). It is crucial 
for reforming the overlapped and disintegrated peatland-related regulations, to ensure the unified peatland management (Stephanie et al. 2017). Synergize policy between national and local government will play a significant role in the current decentralization regime, including resolving stakeholders' competition (Afiff 2015), managing resource and funding management, permit and law enforcement control.

Continuous monitoring and controlling the vital variables such as water-hydrological system, diversity of peats with specific species that higher resistance to disturbances (climate - particularly heat) is necessary. Restoration program needs to be linked to land use and environmental management, to sustain the system itself in future and not just past ones (Wösten, Rieley, \& Page, 2008). Additionally, future Sebangau peatland management needs to strengthen the social capacity, and especially increases the current low degree of people sustainability livelihood (Zakiah et al. 2015), through empowerment and awareness program. Flexible and collaborative social network among societies and institutions also need to be maintained to answer complexity, supported by the adoption of technology.

\section{Conclusion}

Socio-ecological system resilience is defined as the degree of the system that can withstand perturbances while maintaining its fundamental structure and function. In applying the resilience approach to the complex adaptive system such as PSF, it is essential to understand the characteristic and behavior system, to develop the adaptive capacity of the system. Peat swamp forest which has high vulnerability toward external stressor relies mainly on its hydrological system that controls overall peat system. Massive disturbance into one unit of the hydrological system is likely to disturb the entire system, caused severe subsidence, ground water level declined into irreversible condition, which leads to dried and fire-prone peat to drought.

In 1996 Sebangau Peat Swamp Forest was hit by massive destruction under MRP that was aimed to convert peatland to agricultural land. $85 \%$ of the entire peatland subsequently destructed, system resilience eroded and could not withstand to the series of ENSO in the coming years after. The catastrophic condition indicated that the threshold limit of the system has exceeded, and the system shifted into an undesired state. Ecological restoration and designation of post MRP Area into National Park to bring back system function as soon as possible and buffer system from further shocks are considered constructive, even though some destruction still exists such as illegal practices from society and private companies. The adaptive governance reorganizes new regime peatland system with fully embrace diversity, adaptive capacity, for reaching socio-ecological resilient. Social capital and network were gained through engagement and empowerment program particularly to local society inside and surrounding peatland.

For further improvement, the governance needs to reform the attenuations such as disintegrated regulations and policies, lack of sharing authority and funding system, to synergize the implementation of peatland management. Focus on monitoring the essential variables of peatland health and sustainable livelihood also important to leverage the resilience of socioecological system of peat swamp forest. 


\section{References}

Adger, WN 2000, Social and Ecological Resilience: are They Related?, Progress in Human Geography, vol. 24, no.3, pp. 347-364.

Afiff, S 2015, Learning from Green Enclosure Practice in Indonesia: Katingan REDD+ case study project in Central Kalimantan. Chiang Mai, Thailand, BRICS Initiatives for Critical Agrarian Studies (BICAS), MOSAIC Research Project, Land Deal Politics Initiative (LDPI), RSCD Chiang Mai University, Transnational Institute.

Allen, C, \& Gunderson, L 2011, Pathology and Failure in the Design and Implementation of Adaptive Manage, Journal of Environmental Management, vol.92, no.5, pp. 1379-1384.

Berkes, F, \& Folke, C 1998, Linking Social and Ecological Systems: Management Practices and Social Mechanisms for Building Resilience, Cambridge, UK: Cambridge University Press.

Berkes, F, \& Ross, H 2013, Community Resilience: Toward an Integrated Approach, Society and Natural Resources, vol. 26, no.1, pp. 5-20.

Boehm, H. D, \& Siegert, F 2001, Ecological Impact of the One Million Hectare Rice Project in Central Kalimantan, Indonesia, Using Remote Sensing and GIS, Singapore, CRISP, NUS, SISV, and AARS.

Brown, B 2007, Resilience Thinking Applied to The Mangroves of Indonesia, Yogyakarta, Indonesia: IUCN \& Mangrove Action Projects.

Ceruti, M 2016, APRIL Ecosystem Restoration Project: A sustainable model for Indonesian peatlands?, Master thesis in Sustainable Development 315 - the Department of Earth Sciences, Uppsala University, pp. 1-78.

Chapin, FS, Carpenter, SR, Kofinas, GP, Folke, C, Abel, N, Clark, WC, Smith, D, Mark, S, Walker, B, Young, OR, Berkes, F, Biggs, R, Grove, JM, Naylor, RL, Pinkerton, E, Steffen, W, Swanson, FJ 2009, Ecosystem Stewardship: Sustainability Strategies for a Rapidly Changing Planet, Trends in Ecology and Evolution, vol.25, no.4, pp. 241-249.

Chokkalingam, U, Kurniawan, I \& Ruchiat, Y 2005, Fire, Livelihoods, and Environmental Change in the Middle Mahakam Peatlands, East Kalimantan, Ecology and Society, vol. 10, no.1, p. 26.

Cole, LES, Bhagwat, SA \& Willis, KJ 2015, Long-term Disturbance Dynamics and Resilience of Tropical Peat Swamp Forests, Journal of Ecology, vol. 103, pp. 16-30.

Cote, IM, \& Darling, ES 2010, Rethinking Ecosystem Resilience in the Face of Climate Change, PLoS Biology, vol. 8, no. 7, pp. 1-6.

DeCaro, DA, Chaffin, BC, Schlager, E, Garmestani, AS, Ruhl, J.B 2017, Legal and Institutional Foundations of Adaptive Environmental Governance, Ecology and Society, vol. 22, no. 1, p. 32.

Dielman, CM, Branfireun, BA, McLaughlin, JW \& Lindo, Z 2015, Climate change drives a shift in peatland ecosystem plant community: Implications for ecosystem function and stability, Global Change Biology, vol. 21, pp. 388-395.

Folke, C 2006, Resilience: The emergence of a perspective for social-ecological systems analyses, Elsevier: Global Environmental Change, pp. 253-267.

Folke, C, Carpenter, SR, Walker, B, Chapin, T, Rockstrom, J 2010, Resilience Thinking: Integrating Resilience, Adaptability and Transformability, Ecology and Society, vol. 15, no. 4, p. 20.

Germastani, AS, Allen, CR \& Cabezas, H 2009, Panarchy, Adaptive Management and Governance: Policy Options for Building Resilience, Nebraska Law Review, vol. 87, no. 4, pp. 1036-1054.

Government of Indonesia 1998, Government Regulation No. 68/1998 on Natural Sanctuary and Natural Conservation Area, Jakarta: Government of Indonesia.

Gunderson, LH 2000, Ecological Resilience - In Theory and Application, Annual Review Ecology System. 31, pp. 425-429.

Gunderson, LH, Cosens, B \& Garmestani, AS 2016, Adaptive Governance of Riverine and Wetland Ecosystem Goods and Services, Journal of Environmental Management, vol. 183, pp. 353-360.

Gunderson, L \& Holling, C 2002, Panarchy: Undestanding transformations in human and natural systems, Washington D.C, USA: Island Press.

Holling, CS 1973, Resilience and Stability of Ecological Systems, Vancouver: Institute of Resource Ecology, University of British Columbia. 
Jaenicke, J, Wosten, H, Budiman, A \& Siegert, F 2010, Planning hydrological restoration of peatlands in Indonesia to mitigate carbon dioxide emissions, Mitigation Adaptation Strategy Global Change, vol. 15, pp. 223-239.

Miettinen, J, Shi, C \& Liew, SC 2012, Two decades of destruction in Southeast Asia's peat swamp forests, Front Ecological Environment, vol. 10, no.3, pp. 124-128.

Mukul, SA, Rashid, AM, Uddin, MB \& Khan, NA 2016, Role of Non-Timber Forest Products in Sustaining Forest-Based Livelihoods and Rural Households' Resilience Capacity in and around Protected Area: A Bangladesh Study, Journal of Environmental Planning and Management, vol. 59, no.4, pp. 628-642.

Page, S \& Baird, A 2016, Peatlands and Global Change: Response and Resilience, Leeds, United Kingdom: Annual Reviews.

Page, S, Hoscilo, A, Wosten, H, Jauhiainen, J, Silvius, M, Rieley, J, Ritzema, H, Tansey, K, Graham, L, Vasander, H, Limin, Suwido 2009a, Tropical Peatland Fires in Southeast Asia, In: Tropical Fire Ecology. Chichester, UK: Springer Berlin Heidelberg, pp. 263-287.

Page, S, Hoscilo, A, Langner, A, Tansey, K, Siegert, F, Limin, S, Rieley, J 2009b, Restoration Ecology of Lowland Tropical Peatlands in Southeast Asia: Current Knowledge and Future Research Directions, Ecosystem, vol. 12, pp. 888-905.

Parker, SR 2013, Managing for Ecosystem Resilience in Fathom Five National Marine Park, Lake Huron, Canada, Waterloo, Ontario, Canada: University of Waterloo.

Putra, El, Takahashi, H \& Usup, A 2008, Recent Peat Fire Activity in the Mega Rice Project Area, Central Kalimantan, Indonesia, Disaster Research, vol. 3, no. 5, pp. 1-8.

Ritzema, H, Limin, S, Kusin, K, Jauhiainen, J, Wösten, H 2014, Canal blocking strategies for hydrological restoration of degraded tropical peatlands in Central Kalimantan, Indonesia, Catena, vol. 114, pp. 11-20.

Stephanie, E, Yule, Catherine, M, Padfield, R, O'Reilly, P, Varkkey, H 2017, Keep Wetland Wet: the Myth of Sustainable Development of Tropical Peatlands - Implication for Policies and Management, Global Change Biology, vol. 23, no.2, pp. 534-549.

Taman Nasional Sebangau 2014, Taman Nasional Sebangau, [Online]

Available at: https://www.tnsebangau.com/[Accessed 21 May 2017].

Tuittila, ES, Vasander, H \& Laine, J 2000, Impact of Rewetting on the Vegetation of a CutAway Peatland, Applied Vegetation Science, vol. 3, pp. 205-212.

Waddington, JM, Morris, PJ, Kettridge, N, Granath, G, Thompson, DK, Moore, PA 2015, Hydrological feedbacks in northern peatlands, Eohydrology, vol. 8, pp. 113-127.

Walker, B \& Salt, D 2006, Resilience Thinking: Sustaining Ecosystem and People in a Changing World, Washington, DC: Island Press.

Walker, B \& Salt, D 2012, Resilience Practice: Building Capacity to Absorb Disturbance and Maintain Function, Washington, DC: Island Press.

Whitfield, S, Reed, M, Thomson, K, Christie, M, Stringer, LC, Quinn, CH, Anderson, R, Moxey, A, Hubacek, K 2011, Managing Peatland Ecosystem Services: Current UK Policy and Future Challenges in a Changing World, Scottish Geographical Journal, vol. 127, no.3, pp. 209-230.

Wösten, JHM, Clymans, E, Page, SE, Rieley, JO, Limin, SH 2008, Peat-water interrelationships in a tropical peatland ecosystem in Southeast Asia, Catena, vol. 73, pp. 212224.

Wösten, J, Rieley, J \& Page, S 2008, Restoration of tropical peatlands, Wageningen, The Netherlands: Alterra - Wageningen University and Research Centre, and the EU INCO RESTORPEAT Partnership.

WWF Indonesia 2015, WWF Indonesia. [Online] Available at: http://www.wwf.or.id/en/ about_wwf/whatwedo/forest_species/where_we_work/sebangau/aboutsebangau/ [Accessed 20 May 2017].

Wyborn, C 2015, Connecting Knowledge with Action through Co-productive Capacities: Adaptive Governance and Connectivity Conservation, Ecology and Society, vol. 20, no. 1, p. 11.

Yule, CM 2010, Loss of biodiversity and ecosystem functioning in Indo-Malayan peat swamp forests, Biodiversity Conservation, vol. 19, pp. 393-409.

Zakiah, W, Maryunani, Fanani, Z \& Ariyadi, M, 2015, Community Characteristics Sebangau National Park Buffer Zone Based Sustainable Livelihood Approach, Malang, Indonesia: Scientific and Academic Publishing. 